\section{Rootstock Selection, Preplant Soil Treatments, and Tree Planting Positions as Factors in Managing Apple Replant Disease}

\author{
Michelle M. Leinfelder and Ian A. Merwin' ${ }^{1}$ \\ Department of Horticulture, Cornell University, Ithaca, NY 14853
}

Additional index words. Malus $\times$ domestica, compost, soil fumigation, root-lesion nematode, disease resistance, biocontrol, integrated pest management

\begin{abstract}
Apple replant disease (ARD) is a common problem typified by stunted growth and reduced yields in successive plantings of apple (Malus $\times$ domestica Borkh.) in old orchard sites. ARD is attributed to biotic and abiotic factors; it is highly variable by sites, making it difficult to diagnose and overcome. In this experiment, we tested several methods of controlling ARD in a site previously planted to apple for $>\mathbf{8 0}$ years. Our objective was to evaluate practical methods for ARD management. We compared three different experimental factors: four preplant soil treatments (PPSTs) (compost amendments, fumigation with Telone C-17, compost plus fumigation, and untreated soil); two replanting positions (in the old tree rows vs. old grass lanes); and five clonal rootstocks ('M.26', 'M.7', 'G.16', 'CG.6210', and 'G.30') during 4 years after replanting. The PPSTs had little effect on tree growth or yields during 4 years. Tree growth was affected by planting position, with trees planted in old grass lanes performing better than those in the old tree rows. Rootstocks were the most important factor in overcoming ARD; trees on 'CG.6210' and 'CG.30' grew better and yielded more than those on other rootstocks. Rootstock selection and row repositioning were more beneficial than soil fumigation or compost amendments in controlling ARD at this orchard.
\end{abstract}

A disease complex or syndrome known as apple (Malus $\times$ domestica Borkh.) replant disease (ARD) has been reported in fruit growing regions worldwide for more than a century (Mai and Abawi, 1981). Replant disease becomes problematic as growers renovate old orchards and replace them with similar crop species. It is usually attributed not to unfavorable soil and root conditions per se, but to pathogens or other biotic factors in the root zone in conjunction with abiotic soil conditions (McKenry, 1999). The symptoms of ARD are diverse, and its causes are often complex and nonspecific (Mai et al., 1994). New orchards in affected sites do not establish well, and usually show diagnostic symptoms such as stunted growth above and below-ground, nutrient deficiencies, drought stress, reduced yields and increased tree mortality (Mai and Abawi, 1981; Mazzola, 1998).ARD may be less of a hindrance when growers can rotate crop species; but in many areas climate, economics, or other factors limit the fruit crops that can be grown, and replant problems become a serious threat to the tree-fruit industry.

Replant problems impede efforts to replace obsolete or unproductive orchards with new fruit varieties and planting systems (Merwin et al., 2001). Biotic factors have been the focus of most ARD research, because soil fumigation or

Received for publication 6 Oct. 2005. Accepted for publication 22 Dec. 2005. This research was supported by USDA-IREE Methyl Bromide Alternatives projects NYC-145560 and 145-530, and by CSREES project NYC-145409. The authors thank Gennaro Fazio and George Hudler for critical reviews of the manuscript.

${ }^{1}$ Corresponding author for reprint requests: e-mail im13@cornell.edu. steam pasteurization have often improved tree growth and yields in replant sites (Mazzola, 1998; Mai and Abawi, 1981). Chemicals such as Vorlex ( $80 \%$ chlorinated C3 hydrocarbons + $20 \%$ methyl isothiocyanate), Telone C-17 (78\% 1,3-dichloropropene $+17 \%$ chloropicrin), and methyl bromide have increased tree growth in some replant sites (Benson et al., 1978; Costante et al., 1987; McKenry, 1999). Past research has implicated parasitic root-lesion and dagger nematodes (Pratylenchus spp. and Xiphinema spp.) (Mai and Abawi, 1981); various fungal species (Rhizoctonia, Cylindrocarpon, Fusarium, Alternaria, Trichoderma, Phytophthora, and Pythium spp.) (Mazzola, 1998), and possibly bacteria (Bacillus spp) (Utkhede et al., 1992), as rootpathogens involvedinARD. Broad-spectrum soil fumigants have not provided consistent control of ARD, and most fumigants pose problems such as high costs of application, potential human health risks, and environmental degradation such as global ozone depletion(Mazzola, 1998). There is an urgent need for more practical and sustainable ARD control tactics.

Selection ofARD resistant rootstocks offers another method for managing replant disease (Mai and Abawi, 1981; Parker and Mai, 1974; Wilton, 2002a). Clonal rootstocks that reduce tree-size and increase precocity and productivity in high-density plantings have revolutionized the apple industry, but the common dwarfing rootstocks are susceptible to replant problems (Allen and Marks, 1977; Costante et al., 1987). Recent research has indicated that some new rootstocks from the New York State Agricultural Experiment Station (NYSAES) in Geneva-'CG.6210' and 'G.30'-are resistant or tolerant to ARD (Isutsa and Merwin, 2000).
These rootstocks came from a breeding program that screened for seedling resistance to fire blight (Erwinia amylovora) and phytophthora root rot (Cummins and Aldwinckle, 1983). This selection strategy may have inadvertently selected for resistance to some of the pathogens implicated in ARD.

Nonchemical ARD controls investigated recently include soil compost amendments and row repositioning. Compost applications increased apple trunk cross-sectional area, total number of shoots and spurs, shoot length, and overall tree height during the first three years in a Maine orchard (Moran and Schupp, 2001). In a Washington study, fruit-tree growth improved proportionally as more compost was applied (Granatstein and Mazzola, 2001). The mechanisms of compost disease suppression are uncertain, and may involve either increased nutrient availability and/or enhanced populations of beneficial soil microbes (Hoitink and Fahy, 1986; Hoitink and Grebus, 1994). Replanting trees outside of previous orchard tree rows has proven effective in New Zealand (Wilton, 2002b), although this may not be a practical tactic in many situations due to field topography, reduced row spacing in new plantings, preinstalled irrigation lines or other site limitations.

Research on integrated and alternative tactics for managing ARD is a high priority worldwide. Our objectives in this experiment were to investigate the main effects and interactions of four preplant soil treatments, two tree-planting positions, and five dwarfing to semi-dwarfing rootstocks - as individual and combined tactics for ARD control. We tested three main hypotheses in this study. First, preplant soil treatments would chemically or biologically suppress ARD pathogens and increase replant tree growth and yield. Second, trees planted into old grass lanes would be subjected to fewer carry-over ARD pathogens and would grow and yield better than trees planted into old tree rows. Third, rootstock clones would differ in their resistance or tolerance to the site-specific ARD complex at our test orchard.

\section{Materials and Methods}

The experiment was located on a 0.4 -ha site at the Cornell Orchards in Ithaca, N.Y. The soil was a glacial lacustrine silty clay loam (mixed mesic Udic Hapludalf), with a moderate slope and limited soil drainage below $50 \mathrm{~cm}$ depth. Originally planted to apple around 1910 , the site was first replanted in 1981. The second planting established poorly and exhibited diagnostic ARD symptoms including inconsistent and stunted tree growth, poor yields during and after establishment, and high rates of cumulative tree mortality (Mai et al., 1994; McKenry, 1999).

All of the trees remaining from the 1981 planting were removed in September 2001 with a tractor-loader, excavating as much of the old root systems as possible and shaking adhering soil back into each site of removal. The ground was then chiseled plowed at a depth of $40 \mathrm{~cm}$ parallel to the old tree rows, to remove old roots. The locations of each of the 12 previous tree rows and grass lanes were mapped, and ten 
composite soil samples from 0 to $30 \mathrm{~cm}$ deep were collected, sieved and analyzed for essential plant nutrient availability, $\mathrm{pH}$, cation exchange capacity, and organic matter content. Based on these soil analyses, a uniform application of dolomitic lime was distributed over the entire site at a rate of $11 \mathrm{t} \cdot \mathrm{ha}^{-1}$. The soil was then disked in preparation for preplant soil treatments.

Preplant soil treatments. Four treatmentscompost soil amendments, soil fumigation, fumigation plus composting, and an untreated control-were applied during September to October 2001. Treatments were applied in continuous strips perpendicular to the previous tree rows, allowing for evaluation of old tree row vs. old grass lane effects (Fig. 1).

Compost treatments were applied in two portions on 24 Sept. 2001, in 1.5-m-wide bands, with a mechanical row mulcher. The first portion of compost was applied at a rate of $492 \mathrm{~kg}$ per treated hectare to the soil surface and then incorporated into the root zone to a depth of 25 $\mathrm{cm}$ with a moldboard plow. The second portion was applied at the same rate in the same band and then rototilled into the upper $10 \mathrm{~cm}$ of soil. The compost consisted of $40 \%(\mathrm{v} / \mathrm{v})$ ground leaves and wood chips, $40 \%$ supermarket vegetable culls, and $20 \%$ precomposted cattle and horse manure mixed with wood shavings (Toad Hollow Farm, Nedrow, N.Y.). This compost was selected for its high level of biological activity in previous tests by P.D. Millner, USDA-ARS in Beltsville, Md. Available plant nutrient content of the compost was determined by Dumas combustion analysis (for $\mathrm{C}$ and $\mathrm{N}$ ) and inductively coupled argon plasma spectroscopy (for other macro and micronutrients). To compensate for indirect fertilization effects of the compost, all non-composted plots were treated with a mineral fertilizer $(22 \mathrm{~N}-4 \mathrm{P}-0 \mathrm{~K})$ at $318 \mathrm{~kg}$ per treated hectare. Control plots were left untreated except for the N-P-K fertilizer and lime applications.

Following the lime, compost, and fertilizer applications the entire site was rototilled parallel to the intended replant tree rows, to minimize spreading of material among different preplant treatment areas. A hard fescue grass cover ( Festuca duriuscula 'Spartan') was drill seeded at a rate of $50 \mathrm{~kg} \cdot \mathrm{ha}^{-1}$ over the entire site, one day before fumigation treatments.

The soil fumigant Telone C-17 (Dow AgroSciences, Indianapolis, Ind.), composed of 1,3 dichloropropene $(78 \% \mathrm{v} / \mathrm{v})$ and chloropicrin $(17 \% \mathrm{v} / \mathrm{v})$, was shank injected at a depth of $25 \mathrm{~cm}$ and a rate of $400 \mathrm{~L}$ per treated ha on 5 Oct. 2001, and sealed with a heavy cultipacker immediately after application. This was the final preplant soil treatment application. In the compost plus fumigation plots, both compost and fumigation were applied as described above, with fumigation occurring $10 \mathrm{~d}$ after compost incorporation. All trees were planted on $13 \mathrm{Nov}$. $2001,40 \mathrm{~d}$ after soil fumigation. Soil and weather conditions between fumigation and tree planting were warm and dry - optimal for soil penetration and dissipation of the fumigant.

Rootstock selection and planting. Five dwarfing and semi-dwarfing rootstock varieties were selected for comparison in this study. Two of these clonal rootstocks-'M.26' and 'M.7'-are commonly used in commercial orchards throughout North America. The other three rootstocks were recently introduced by the NYSAES in Geneva, N.Y. These three newer rootstocks-'G.16', 'CG.6210', and 'G.30' - are among the Cornell-Geneva series, where the letter $\mathrm{G}$ designates rootstocks that have been formally released and the letters CG designate those that are not yet commercially available. For the five rootstocks in our main experiment, expected scion vigor or tree-size at maturity were as follows, from smaller to larger: 'G.16' < 'M.26' <' CG.6210' = 'M.7' $=$ 'G.30' (Robinson et al., 2002). Trees for this study were custom propagated for us by Wafler Nursery (Wolcott, N.Y.) with 'Royal Empire' as the scion variety.

The replant tree rows were oriented north to south (perpendicular to the previous old orchard) with a spacing of $2.1 \mathrm{~m}$ in rows and 4.9 $\mathrm{m}$ between rows. Preplant soil treatments were randomized within five replicate blocks (Fig. 1). The five rootstock genotypes were randomized and replicated within each block and planting position, so that half of the replant trees were situated in the previous old tree rows, and the other half were in the previous grass drive lanes. The experimental treatment arrangement was essentially two overlapping split-split-plot grids arranged in Latin squares, which enabled us to test three different factors at once. Each tree comprised an experimental unit, uniquely defined by its block, preplant soil treatment, rootstock, and planting position. The preplant soil treatments, rootstocks, and positions were fixed effects, and blocks were random effects. All of the trees in one position (old grass lane or old tree row) composed one Latin square, and all of the trees in the opposite position composed the second Latin square. Thus, a rootstock never appeared twice within the same column or row of a given Latin square.

Orchard management. Drip irrigation was provided during mild droughts in July to August 2002 and 2005, but was not necessary during other years of this study. Above-ground arthropod and fungal pests were controlled as needed, using typical practices for commercial orchards in New York (Agnello et al., 2004). The fine-leaf fescue grass in drive lanes was mowed periodically, and glyphosate herbicide was applied in a 1.5 -m-wide strip (at $3.0 \mathrm{~kg}$ active ingredient per treated ha) in May and July annually to control weeds in the tree rows. Two nitrogen applications were made to improve tree growth in the second year of observations (2003). Ammonium nitrate ( $34 \mathrm{~N}-0 \mathrm{P}-0 \mathrm{~K})$ was side-dressed in May at $19.3 \mathrm{~g} / \operatorname{tree}\left(18.7 \mathrm{~kg} \cdot \mathrm{ha}^{-1}\right)$ and calcium nitrate $(15.5 \mathrm{~N}-0 \mathrm{P}-0 \mathrm{~K}-19 \mathrm{Ca})$ was

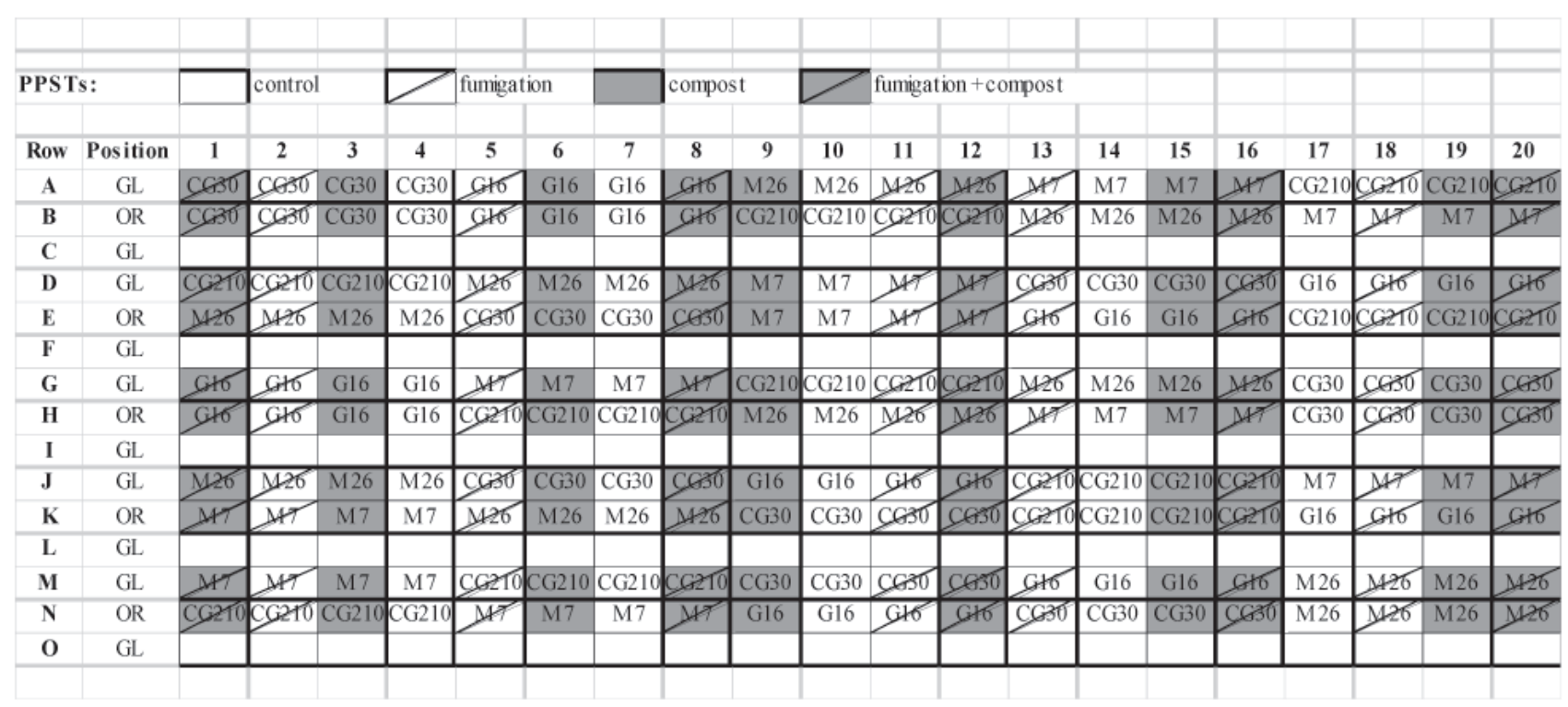

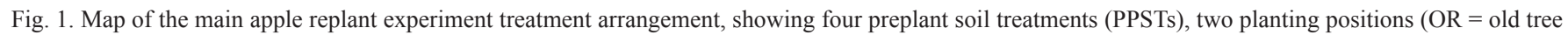
row, $\mathrm{GL}=$ old grass lane), and five rootstock varieties ('CG.(6)210', 'G.30', 'M.7', 'G.16', and 'M.26'. The five replicate blocks are in sets of four contiguous columns (numbered 1 to 20 ), and the five row-pairs are in sets of two juxtaposed rows (lettered A to N). Trees in a different experiment on 'M.9' rootstocks (not shown on map or described in text) occupied rows C, F, I, L, and O. 
applied to foliage in mid-summer cover sprays at a total rate of $17.6 \mathrm{~g} /$ tree $\left(17.1 \mathrm{~kg} \cdot \mathrm{ha}^{-1}\right)$.

Trees were pruned in late winter each year to a modified vertical axe form, using minimal pruning and intensive branch spreading during the first 2 years. Pruning consisted mainly of double leader and co-dominant lateral branch removal. Any flowers that appeared during the first two growing seasons were removed to promote vegetative growth. In Spring 2004, the trees flowered profusely and set a substantial crop that was chemically thinned at the end of May using naphthalene-acetic acid (NAA at $30 \mathrm{~mL} / 380 \mathrm{~L}$ water, v/v) and carbaryl (as Sevin XLR at $0.47 \mathrm{~L} / 380 \mathrm{~L}$ water, v/v) applied uniformly throughout the planting. Streptomycin and calcium prohexadione (formulated as Apogee, BASF, Ludwigshafen, Germany) were applied once at $170 \mathrm{~g} / 380 \mathrm{~L}$ water $(\mathrm{w} / \mathrm{v})$, to all trees in mid-May of 2004 to prevent a fire-blight infection.

Soil and leaf sampling. Soil nutrient supply was analyzed in July 2002 and 2003 for each preplant soil treatment and planting position combination. Four soil cores $(2.54 \mathrm{~cm}$ in diameter) were taken from the upper $25 \mathrm{~cm}$ of soil, about 25 to $30 \mathrm{~cm}$ around the base of each tree. Samples were analyzed for nutrient content, $\mathrm{pH}$, and organic matter by the Cornell Nutrient Analysis Laboratory (Bradfield Hall, Cornell University). In 2002, soil was also sampled for plant-parasitic nematode populations, as determined at the laboratory of George Abawi at the NYSAES in Geneva, N.Y. Nematodes were extracted by a modified Baermann funnel method (Niblack and Hussey, 1985), using pie pans to sieve and decant.

Leaf samples were collected for nutrient analysis in August 2003 and 2004, according to procedures outlined by Stiles and Reid(1991). In 2003, about 15 leaves were collected from each rootstock $\times$ preplant soil treatment $\mathrm{x}$ position combination (i.e., from all 250 trees). To reduce analytic costs, in 2004 we collected leaf samples only from each rootstock $\times$ preplant soil treatment combination (i.e., from each of 125 trees in the old grass-lane positions). Leaves were dried at $80{ }^{\circ} \mathrm{C}$ to constant weight, and analyzed for nutrient content as previously described.

Growth and yield measurements. Trunk caliper was measured before budbreak in March 2002 , to determine the initial tree size at planting. Two caliper measurements were taken for each tree at $45 \mathrm{~cm}$ above the ground. In December 2002 , caliper was again measured, along with central leader and lateral extension growth, to determine first-year growth. Subsequent annual tree growth was measured in midwinter 2003 and 2004 as caliper, central leader, and lateral extension growth. Two crops were harvested (30 Sept. 2004 and 3 Oct. 2005) and yields were recorded separately for each tree, as total fruit weight and number of fruit.

Statistical analyses. All statistical analyses were performed using SAS computer software (SAS Institute, Cary, N.C.). Analysis of variance was used to compare growth, yield, soil nutrient, and leaf nutrient data. The two caliper measurements were averaged and converted into trunk cross-sectional area (TCSA) values, and growth analyses were based on the change in
TCSA. Central leader and lateral growth were also analyzed each year. Lateral shoot growth measurements were averaged for analysis, and the initial TCSA at planting was used as a covariate in subsequent tree growth and yield analyses. Yield was analyzed as total fruit count per tree, total fruit weight per tree, average individual fruit weight, and crop density (number of fruit per square centimeter TCSA). Statistical differences were based on least-squares means separated by Tukey separation procedures. All main-factor differences were based on $P$ values of 0.05 ; interactions were tested at $P=0.20$ as advised by a statistical consultant(F. Vermeylen, personal communication), because the interactions of experimental factors were of particular interest in this study.

\begin{tabular}{|c|c|c|}
\hline $\begin{array}{l}\text { Preplant soil treatment or } \\
\text { planting position }\end{array}$ & $\begin{array}{l}\text { No. } / 100 \mathrm{~cm}^{3} \text { soil } \\
\text { July } 2002\end{array}$ & $\begin{array}{l}\text { No. } / 100 \mathrm{~cm}^{3} \text { soil } \\
\text { October } 2002\end{array}$ \\
\hline Control & $86 \mathrm{a}$ & $128 \mathrm{a}$ \\
\hline Compost & $38 \mathrm{~b}$ & $64 \mathrm{a}$ \\
\hline Fumigation & $0 \mathrm{c}$ & $8 \mathrm{a}$ \\
\hline Compost and fumigation & $34 \mathrm{~b}$ & NA \\
\hline Old tree row & $0.1 \mathrm{~B}$ & NA \\
\hline Old grass lane & $79 \mathrm{~A}$ & NA \\
\hline
\end{tabular}

Table 2. Soil nutrient content ( $\mathrm{mg} \cdot \mathrm{kg}^{-1}$ soil) in Oct. 2002. Mean values represent four preplant soil treatments (PPSTs) and two planting positions. Least-squares means followed by different letters within each column are statistically different $(P=0.05, \mathrm{n}=40)$ and represent Tukey's HSD separations among PPSTs, planting positions, or PPSTs within planting positions.

\begin{tabular}{lccc}
\hline PPST or position & $\mathrm{P}\left(\mathrm{mg} \cdot \mathrm{kg}^{-1}\right)$ & $\mathrm{K}\left(\mathrm{mg} \cdot \mathrm{kg}^{-1}\right)$ & $\mathrm{Mg}\left(\mathrm{mg} \cdot \mathrm{kg}^{-1}\right)$ \\
\hline Control & $4.3 \mathrm{ab}$ & $179.9 \mathrm{~b}$ & $300.9^{\mathrm{NS}}$ \\
Compost & $13.8 \mathrm{a}$ & $230.3 \mathrm{a}$ & $294.3^{\mathrm{NS}}$ \\
Fumigation & $3.6 \mathrm{~b}$ & $173.2 \mathrm{~b}$ & $315.0^{\mathrm{NS}}$ \\
Compost-fumigation & $13.1 \mathrm{a}$ & $231.4 \mathrm{a}$ & $314.4^{\mathrm{NS}}$ \\
SE PPST & 2.6 & 11.5 & 8.7 \\
Old tree row (OR) & $6.5^{\mathrm{NS}}$ & $216.1 \mathrm{a}$ & $301.9^{\mathrm{NS}}$ \\
Old grass lane (GL) & $11.0^{\mathrm{NS}}$ & $191.2 \mathrm{~b}$ & $310.4^{\mathrm{NS}}$ \\
SE position & 1.8 & 7.8 & 8.6
\end{tabular}

PPST or position

Control $\quad \mathrm{Fe}\left(\mathrm{mg} \cdot \mathrm{kg}^{-1}\right) \quad \mathrm{Zn}(\mathrm{mg}$

Compost

Fumigation

Compost-fumigation

SE PPST

Old tree row (OR)

Old grass lane (GL)

SE position

PPST or position

Control
Compos

Fumigatio

Compost-fumigation

SE PPST

Old tree row (OR)

Old grass lane (GL)

SE position

PPST $\times$ position

Control in OR

Compost in OR

Fumigation in OR

Compost-fumigation in OR

Control in GL

Compost in GL

Fumigation in GL

Compost-fumigation in GL

SE PPST $\times$ position

$5.7 \mathrm{a}$

$3.0 \mathrm{c}$

$5.5 \mathrm{ab}$

$3.5 \mathrm{bc}$

0.5

$4.6^{\mathrm{NS}}$

$4.2^{\mathrm{NS}}$

0.3

$\mathrm{Cu}\left(\mathrm{mg} \cdot \mathrm{kg}^{-1}\right)$

$(\mathrm{mg} \cdot \mathrm{kg}$

$0.6 \mathrm{~b}$

$1.4^{\mathrm{NS}} \quad 1.1 \mathrm{a}$

$1.3^{\mathrm{NS}} \quad 0.7 \mathrm{~b}$

$1.7^{\mathrm{NS}} \quad 1.3 \mathrm{a}$

0.2

$1.2^{\mathrm{NS}}$

$1.8^{\mathrm{NS}}$

0.2

0.1

$0.9^{\mathrm{NS}}$

$0.9^{\mathrm{NS}}$

0.5

$\mathrm{B}\left(\mathrm{mg} \cdot \mathrm{kg}^{-1}\right)$

$0.5 \mathrm{~b}$

$0.6 \mathrm{ab}$

$0.5 \mathrm{~b}$

$0.6 \mathrm{a}$

0.0

$0.5^{\mathrm{NS}}$

$0.6^{\mathrm{NS}}$

0.3

\section{$\mathrm{pH}$}

pH $\quad$ OM (\%)

$6.9 \mathrm{a}-4.8 \mathrm{~b}$

$5.8 \mathrm{~b} \quad 4.8 \mathrm{~b}$

6.9 a $\quad 5.9$ a

$0.1 \quad 0.2$

$6.3^{\mathrm{NS}}$

$6.4^{\mathrm{NS}}$

0.1

$4.5 \mathrm{~b}$

$6.0 \mathrm{a}$

0.1

"Significant differences between positions within a preplant soil treatment based on Tukey's HSD mean separation test. 
treatments during our study.

Nutrient availability differed among preplant soil treatments in both 2002 and 2003 (Tables 2 and 3), and followed similar trends in both years. Macronutrient levels tended to be higher in the compost and the compost-fumigation plots, where the soil $\mathrm{pH}$ was more neutral. Micronutrient concentrations were generally higher in fumigation and control plots, where soil $\mathrm{pH}$ was more acidic. In 2002, organic matter $(\mathrm{OM})$ content was significantly greater in all compost, compost-fumigation, and grass lane plots; however, 1 year later soil OM content remained greater only in old grass lane positions that had been treated with compost.

Foliar nutrient concentrations did not follow any apparent trends based on preplant soil treatments, planting positions, rootstocks, or main factor interactions in any year (data not shown). In most cases, differences in leaf nutrient content were not significant at $P=$ 0.05 . When there were statistical differences, all of the observed values remained within the standard nutrient sufficiency ranges for apple in New York established by Stiles and Reid (1991).

Trunk cross-sectional growth. Tree growth in trunk cross-sectional area showed a significant rootstock by position interaction in 2002 (Fig. 2). Trees on 'CG.6210'produced the most growth in both old tree row and old grass lane positions. There was a trend for trees on ' $\mathrm{G} .16$ ', 'M.7', and 'M.26' to grow more in the old grass lanes than in old tree rows (Fig. 2A).

Trunk cross-sectional area increase in 2002 also showed a PPST $\times$ position interaction (Fig. 2B). In the old grass lane positions, trees in control plots grew more than those in fumigated plots. Control trees in old grass lanes also grew more than control trees within old tree rows. However, there were no differences in TCSA growth among PPSTs within the old tree rows.

In 2003, a significant rootstock $\times$ position interaction occurred for TCSA growth (Fig. 2C). Trunk growth on 'CG.6210' exceeded that on all other rootstocks in both planting positions, and tree growth on 'G.16', 'M.7', and 'M.26' was greater in old grass lanes compared with old tree rows. No differences were observed in TCSA growth among the four PPSTs during 2003.

Growth in TCSA declined during the first cropping year of 2004, but the relative trends were consistent with previous years. Once again, trees on 'CG.6210' produced more trunk growth than those on other rootstocks (Fig. 2D). Trees on 'G.30' were the second largest, followed by 'M.7', 'G.16', and 'M.26', and trees in untreated control plots grew more in old grass lanes than in old tree rows (Fig. $2 \mathrm{E}$ ) but no PPST main effects were observed in 2004.

Central leader extension growth. In 2002 , there was a rootstock $\times$ position interaction, with trees on 'CG.6210' growing taller than those on other rootstocks in old tree rows and grass lanes (Fig. 3A). Trees on 'G.16', 'M.7', and 'M.26' also showed enhanced growth in old grass lanes. When planted in old grass lanes, central leader growth on 'G.30', 'G.16', and 'M.7' was similar to 'CG.6210' growth in those positions, while trees on 'M.26' remained much shorter.

During 2003, the trees on 'CG.6210', 'G.30', and 'M.7' all increased similarly in height, and were taller than trees on 'M.26' and ' G.16' rootstocks (Fig. 3B). Central leader growth in 2003 was greater for all trees planted in old grass lane vs. old tree row positions, regardless of rootstocks or PPSTs (Fig. 3C). There were no significant main effect differences among the PPSTs in either 2002 or 2003.

Lateral shoot growth. Lateral extension shoot growth trends in 2002 resembled those for central leader growth in that year. Trees on 'CG.6210' grew similarly in both old tree rows and old grass lanes, and replanting in old grass lanes improved growth on 'G.16' and 'M.7' such that it was not different from growth on 'CG.6210' in those planting positions (Fig. 4A). Again, there were no main effect shoot-growth differences among PPSTs.

Comparing lateral extension shoot growth in 2003, the differences among rootstocks resembled those observed for central leader growth that year (Figs. 4B vs. 3B). Trees on 'CG.6210', 'G.30', and 'M.7' all performed equally well and produced more shoot growth than trees on 'G.16' and 'M.26'. In 2003 we observed the first instance of a significant PPST main effect on tree growth, but the trends were ambiguous (Fig. 4C). Tree shoot growth was reduced in fumigated plots compared with compost plots, but neither differed from the untreated controls or the compost plus fumigation treatment.

Fruit yields. There were substantial differences in crop yields among rootstocks in 2004 and 2005, and the trends were consistent with observed rootstock effects on tree growth in the prebearing years (Fig. 5A). Trees on 'CG.6210' produced more fruit weight per tree than all other rootstocks. Despite these differences in total yields per rootstock, fruit size was similar among all rootstocks and typical for 'Royal Empire' trees both years, with average values ranging from 0.13 to $0.15 \mathrm{~kg} /$ fruit. Trees on 'G.30' produced the second greatest yields, while 'G.16', 'M.7', and 'M.26' were the least productive rootstocks. Apart from the rootstock factor, neither planting position nor PPSTs had any significant effects on fruit yields in 2004 or 2005.

To normalize fruit yield differences among five rootstocks with different effects on scion vigor, we compared crop density - the total number of fruit per unit of TCSA for trees

Table 3. Soil nutrient content (mg $\cdot \mathrm{kg}^{-1}$ soil) in August 2003. Soil was characterized by four preplant soil treatments (PPST) and two planting positions. Least-squares means followed by different letters within each column are statistically different based on Tukey's HSD tests $(P=0.05, \mathrm{n}=40)$ and represent differences among PPSTs, positions, or PPSTs within positions.

\begin{tabular}{lccc}
\hline PPST or position & $\mathrm{P}\left(\mathrm{mg}^{\mathrm{kg}} \mathrm{kg}^{-1}\right)$ & $\mathrm{K}\left(\mathrm{mg} \cdot \mathrm{kg}^{-1}\right)$ & $\mathrm{Mg}\left(\mathrm{mg} \cdot \mathrm{kg}^{-1}\right)$ \\
\hline Control & $2.4 \mathrm{~b}$ & $111.1 \mathrm{~b}$ & $245.2^{\mathrm{NS}}$ \\
Compost & $13.8 \mathrm{a}$ & $156.5 \mathrm{a}$ & $276.2^{\mathrm{NS}}$ \\
Fumigation & $2.5 \mathrm{~b}$ & $110.1 \mathrm{~b}$ & $266.3^{\mathrm{NS}}$ \\
Compost-fumigation & $9.1 \mathrm{ab}$ & $132.6 \mathrm{a}$ & $250.5^{\mathrm{NS}}$ \\
SE PPST & 1.8 & 8.9 & 17.0 \\
Old tree row (OR) & $5.9^{\mathrm{NS}}$ & $139.7^{\mathrm{NS}}$ & $265.1^{\mathrm{NS}}$ \\
Old grass lane (GL) & $8.0^{\mathrm{NS}}$ & $115.4^{\mathrm{NS}}$ & $254.1^{\mathrm{NS}}$ \\
SE position & 1.5 & 8.3 & 13.3
\end{tabular}

PPST or position

Control

Compost

Fumigation

$\mathrm{Ca}\left(\mathrm{mg} \cdot \mathrm{kg}^{-1}\right)$

$\operatorname{Mn}\left(\mathrm{mg} \cdot \mathrm{kg}^{-1}\right)$

$\mathrm{Fe}\left(\mathrm{mg}^{\mathrm{kg}} \mathrm{kg}^{-1}\right)$

Compost-fumigation

SE PPST

Old tree row (OR)

Old grass lane (GL)

SE position

2714.9 a

$1111.0 \mathrm{~b}$

$1.1^{\mathrm{Ns}}$

$9.0 \mathrm{a}$

$2125.5 \mathrm{a}$

207.5

$13.5^{\mathrm{NS}}$

$4.4 \mathrm{~b}$

$8.6 \mathrm{a}$

$15.2^{\mathrm{NS}}$

$5.3 \mathrm{~b}$

$1660.6^{\mathrm{NS}}$

1.3

$1828.6^{\mathrm{NS}}$

$14.7^{\mathrm{NS}}$

136.0

$13.4^{\mathrm{NS}}$

1.1

$6.2^{\mathrm{NS}}$

PPST or position

Control

Compost

$\mathrm{Zn}\left(\mathrm{mg} \cdot \mathrm{kg}^{-1}\right)$

0.8

$7.4^{\mathrm{NS}}$
0.8

Fumigation

$2.6^{\mathrm{NS}}$

$2.7^{\mathrm{NS}}$

$\mathrm{Cu}\left(\mathrm{mg} \cdot \mathrm{kg}^{-1}\right)$

$\mathrm{pH}$

Compost-fumigation

SE PPST

Old tree row (OR)

Old grass lane (GL)

SE position

$17.0^{\mathrm{NS}}$

$1.5^{\mathrm{NS}}$

6.7

$2.6^{\mathrm{NS}}$

$9.4^{\mathrm{NS}}$

4.6

$0.7 \mathrm{ab}$

$1.0 \mathrm{a}$

$0.6 \mathrm{~b}$

$0.9 \mathrm{ab}$

0.1

$0.8^{\mathrm{NS}}$

$0.9^{\mathrm{NS}}$

0.1

$6.0 \mathrm{~b}$

7.0

$6.2 \mathrm{~b}$

$6.9 \mathrm{a}$

0.2

$6.5^{\mathrm{NS}}$

$6.5^{\mathrm{NS}}$

PPST $\times$ position

Organic matter $(\%)$

Control in OR

Compost in OR

Fumigation in OR

$3.6^{\mathrm{N}}$

$4.9^{\mathrm{NS}}$

Compost-fumigation in OR $\quad 4.7^{\mathrm{NS}}$

Control in GL

$4.0 \mathrm{~b}$

Compost in GL

$6.9 \mathrm{a}^{*}$

$4.0 \mathrm{~b}$

Fumigation in GL

$5.1 \mathrm{ab}$

SE PPST $\times$ position

0.4

NS," Indicates significant differences between positions within a preplant soil treatment (significant preplant soil treatment $\times$ position interaction) using Tukey's mean separation. 


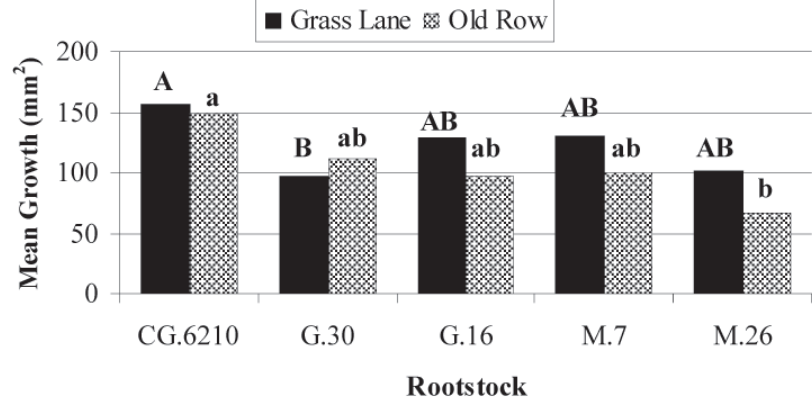

(B) Increase in TCSA among PPSTs and planting positions during 2002

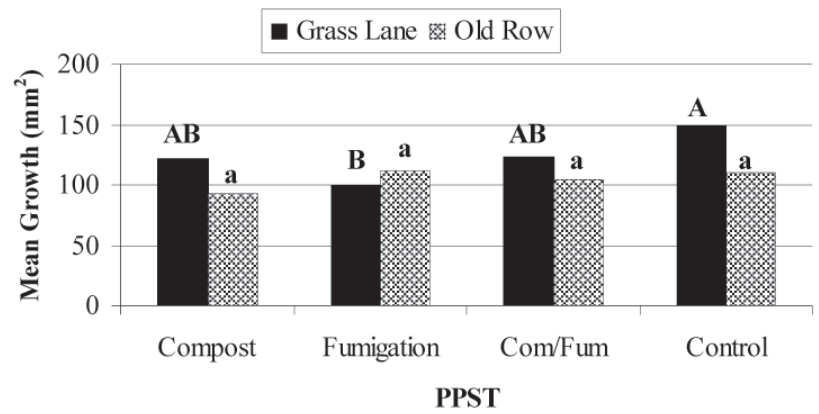

(C) Increase in TCSA among rootstocks and planting positions during 2003

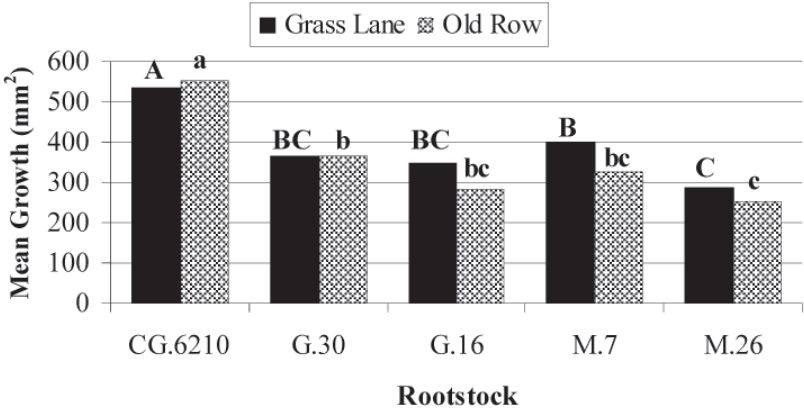

(D) Increase in TCSA among rootstocks during 2004

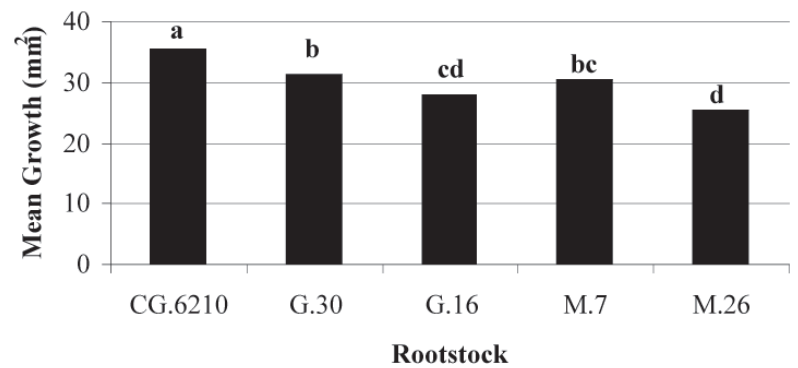

(E) Increase in TCSA for trees in old grass lanes (GL) vs. old rows (OR) during 2004

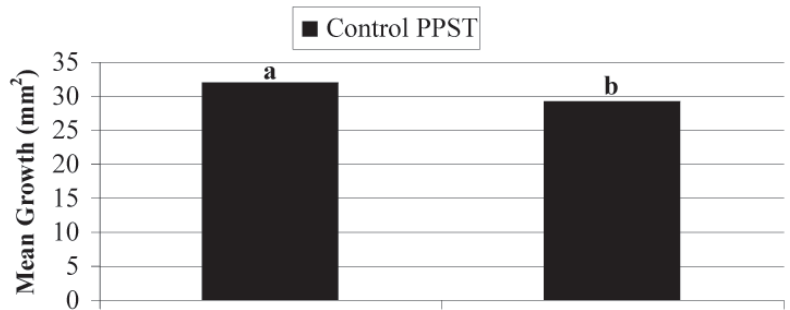

GL

OR

Position previous reports that nematicides and broadspectrum biocides can suppress plant-parasitic nematodes involved in ARD (Mai and Abawi, 1981; Mai et al., 1994). The compost treatment also kept $P$. penetrans in check for eight months relative to untreated plots, but fumigation was less effective in nematode suppression when it was combined with compost, perhaps because the increased soil OM content in compost treatments (Table 2) interfered with fumigant activity.

The nematode suppression by compost treatments at our site was consistent with previous studies published by Forge et al. (2000) and Hoitink and Fahy (1986). Their composting and fumigation results showed that these treatments could reduce populations of this pest in orchards where it was a potential threat. We also noted that root-lesion nematodes were more abundant in old grass lanes than in old tree rows (Table 1), suggesting that this nematode-which has a broad host-plant range - could survive and reproduce more in a grass-dominated rhizosphere than in the apple-dominated rhizosphere of herbicide treated tree rows. Similar observations were reported by Merwin (1995), in a previous study where herbicide-treated plots in an apple orchard sustained fewer root-lesion nematodes than plots under herbaceous groundcovers. The increased growth of trees planted in old grass lanes, where there were more root-lesion nematodes, indicated that $P$. penetrans was not an important factor in the ARD complex at this orchard.

Soil and leaf analyses. We analyzed soil and leaf nutrient content to determine if they influenced tree growth or yields and were a significant factor in ARD at this site. There were substantial differences in soil $\mathrm{P}, \mathrm{K}, \mathrm{Ca}$, $\mathrm{Mn}, \mathrm{Fe}, \mathrm{Cu}$, and $\mathrm{B}$ availability, soil $\mathrm{pH}$ and $\mathrm{OM}$ among the PPSTs, and between the two planting positions (Tables 2 and 3). Nonetheless, only a few significant leaf content differences were observed, and foliar nutrient concentrations remained at levels sufficient for tree nutrition and development in all treatments during this study (Stiles and Reid, 1991). Neither soil nor leaf nutrients were correlated with observed tree growth or yield differences, and we concluded that nutritional problems were not a limiting factor in this study, despite their reported roles in ARD at some other N.Y. orchards (Mai et al., 1994).

Tree growth analyses. In regard to preplant soil treatments, rootstock selection, and planting position impacts on tree growth, diverse inferences can be made from our experiment. Differences in tree growth among the four PPSTs were rarely significant, and when difconsistent with

Fig. 2. The yearly increase in trunk cross-sectional area (TCSA) for 2002 to 2004. (A and C) Rootstock $\times$ position interactions in 2002 and 2003 , respectively. Capital letters above mean values indicate differences in rootstock least squared means within the old grass lanes, and lowercase letters indicate differences in rootstock least squared means within old tree rows $(P=0.05)$. (B) PPST $\times$ position interactions in 2002 . Capital letters indicate Tukey HSD differences between preplant soil treatments in the old grass lanes $(P=0.05)$. (D) Rootstock main effects in 2004. Different letters indicate differences in least-squares means $(P=0.05)$. (E) PPST $\times$ position interactions in 2004 . 


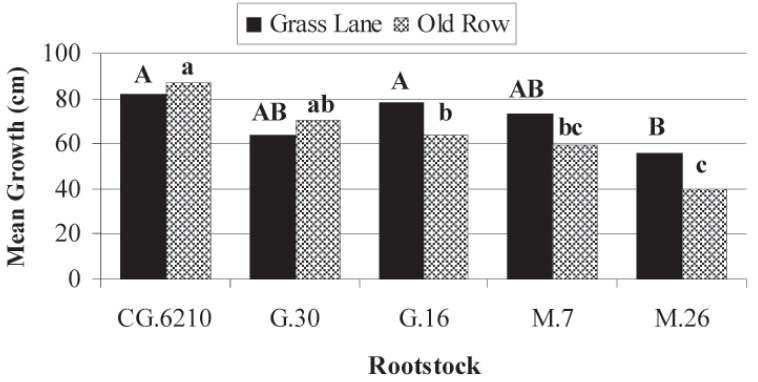

(B) Increase in Central Leader growth among rootstocks during 2003

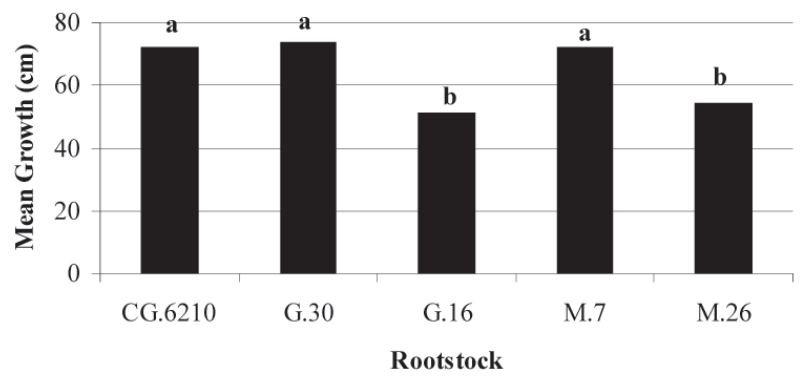

(C) Increase in Central Leader growth among planting positions during 2003

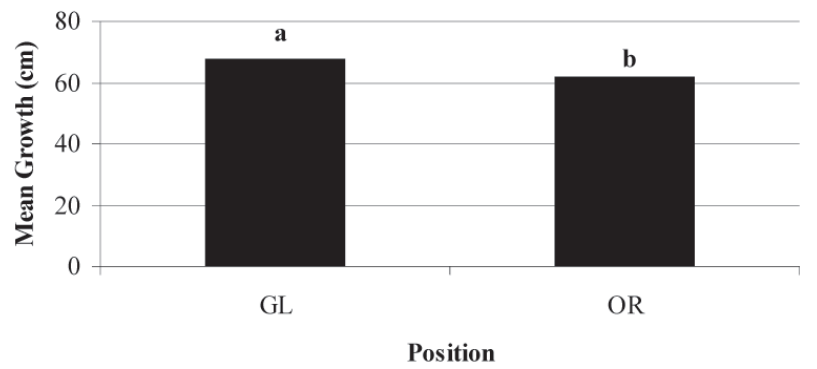

Fig. 3. Change in central leader growth for 2002 and 2003. (A) Rootstock $\times$ position interaction in 2002. Statistical differences as described in Fig. 2A and C. (B) Rootstock main factor effect in 2003. (C) Position main factor effects in 2003. Main factor effects as described in Fig. 2D.

ferences were detected the untreated control trees often performed relatively well. There was a positive shoot growth response of trees in compost plots compared with fumigation in 2003 (Fig. 4C), but it was not statistically different from that of trees in control plots. Hoitink and Grebus (1994) noted that compost quality and efficacy in biological control are contingent upon the curing, consistency and stability of each mixture. The lack of treegrowth improvement in compost plots during the first year of our study may indicate that the compost needed more stabilization time. This interpretation would be consistent with the improved tree growth observed in compost treatments during the second year (Fig. 4C). In related tests of soil samples from compost treated plots in our study, Rumberger et al. (2004) observed higher soil microbial respiration rates in compost treatments, which might be expected to influence root and tree nutrient uptake. Nevertheless, tree growth improvements in compost treatments were minor compared with rootstock effects, and

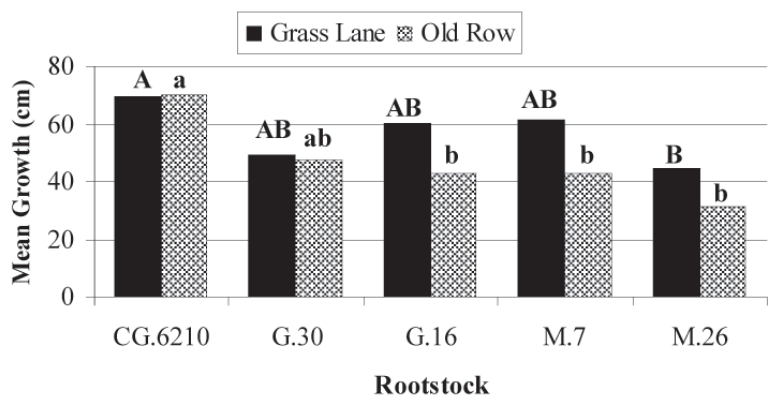

(B) Lateral extension growth among rootstocks in 2003

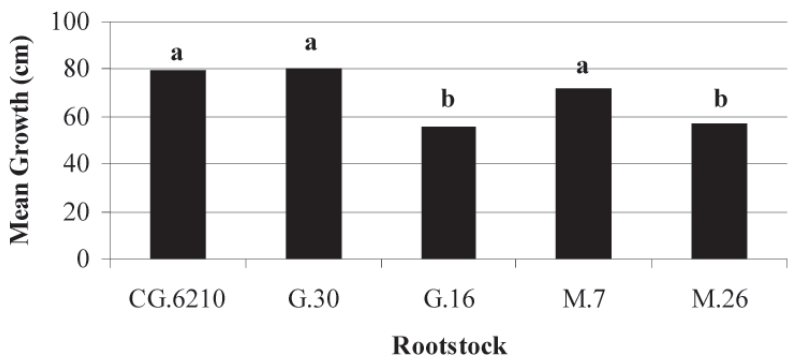

(C) Lateral extension growth among PPSTs in 2003

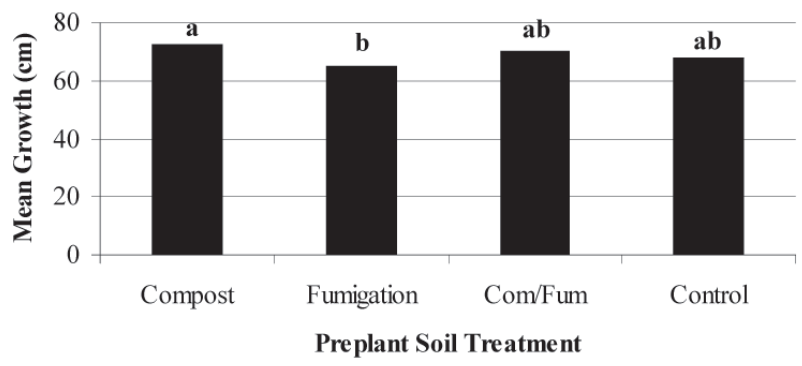

there were no yield gains to offset the high costs of compost treatments.

Preplant soil fumigation did not cause the improvements in tree growth and yields that have been reported in some previous ARD studies (Mai andAbawi, 1981; McKenry, 1999; Savory, 1966; Smith, 1994). In fact, trees in both fumigation treatments produced less trunk and shoot growth than those in compost and untreated control plots during 2002 and 2003 (Figs. 2B and 4C). Similar interference has been observed in peach plantings in South Carolina and almond groves in California (G. Reighard and E. Hsoda respectively, unpublished data). Although we adhered to label recommendations for the interim delay period between soil fumigation and replanting, it is possible that more time was necessary to allow for complete dissipation of phytotoxic fumigant residues under the specific soil conditions in our site.

An alternative interpretation of our results is that soil fumigation may not be consistently effective for controlling ARD at some replant sites. In a 5-year-long series of experiments at 20 orchards throughout New York, Merwin et al. (2001) observed insignificant or detrimental apple tree responses to preplant soil fumigation with Telone C-17 and metam sodium on farms where site histories and preplant diagnostic bioassays had indicated ARD problems. The soil fumigant in our study was a broad-spec-
Fig. 4. Yearly increases in lateral extension shoot growth for 2002 and 2003. (A) Shows rootstock $\times$ position interaction 2002. Statistical differences as described in Figs. 2A and C. (B) Shows rootstock main factor effect in 2003. (C) Shows PPST main factor effect in 2003. Main factor effects as described in Fig. 2D.

trum biocide that could reduce beneficial soil microbial populations as well as root pathogens. Rumberger et al. (2004) found that bacterial colony-forming-unit counts in apple rhizosphere soil were reduced by fumigation in comparison with compost treatments at our test site. Using DNA fingerprinting techniques to assess the impacts of our PPSTs, Yao (2005) also reported that soil fumigation and compost treatments altered for several years the soil bacterial and fungal communities within the tree rows at this orchard, but these effects were not correlated with positive or negative tree-growth responses.

Rootstocks have been evaluated for adaptability and performance under diverse soil conditions in many regions, including sites with ARD problems (Cummins and Aldwinckle, 1983; Mai and Abawi, 1981; Savory, 1966; Wilton, 2002a). In our site, trees on both 'CG.6210' and 'G.30' rootstocks grew and yielded similarly in old grass lanes and tree rows, across all the PPSTs during 4 years of 


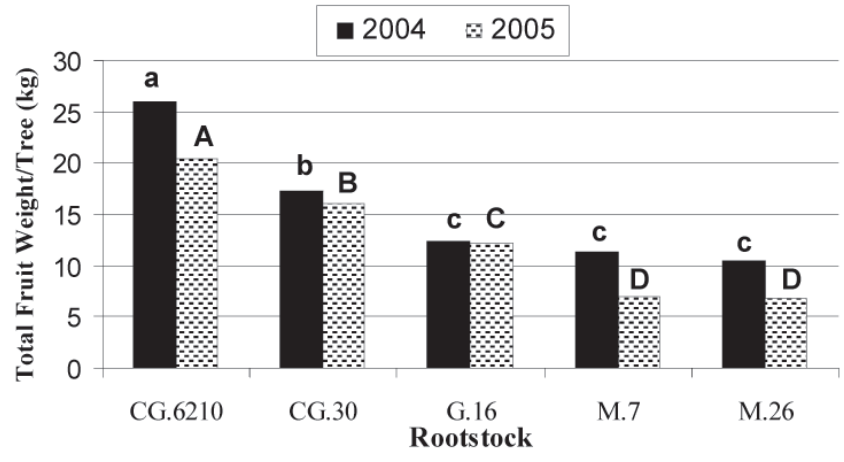

(B) Crop density among rootstocks and PPSTs in 2004

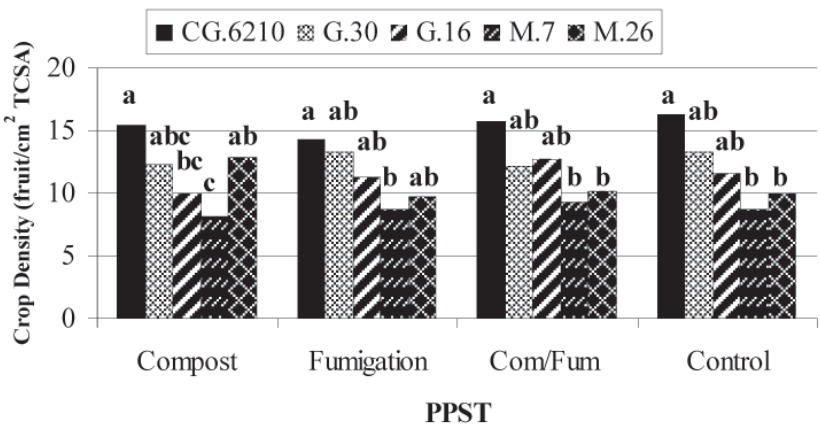

Fig. 5. Fruit yields in 2004 and 2005. (A) Total fruit weight, with rootstock main factor effect as described in Fig. 2D. (B) Crop density, with rootstock $\times$ PPST interaction. Different letters indicate Tukey HSD differences in least-squares means $(P=0.05)$ among the rootstocks within each PPST.

observations. The advantages of 'CG.6210' and 'G.30' rootstocks in ARD situations were noted previously by Isutsa and Merwin(2000), who reported that of 940 different Malus accessions and species evaluated, these two rootstocks were some of the most tolerant or resistant to root pathogens implicated in ARD. Robinson et al. (2002) observed that trees on 'CG.6210' and 'G.30' grown in untreated soil at replant sites were actually somewhat more vigorous than those grown in disinfested soil. These studies indicate that 'CG.6210' and 'G.30' may have useful inherent tolerance to the ARD complex.

Pathogens that establish over many decades in old-row soil on the common Malling series rootstocks may be less capable of parasitizing the roots of recently developed rootstocks such as the Cornell-Geneva series. However, the observations of Rumberger et al. (2004) suggest another interpretation. Their study found quantitative and qualitative differences in soil microbial communities in old orchard grass lanes vs. tree-row positions, and on 'CG.6210' and 'G.30' vs. 'M.7' and 'M.26' rootstocks, suggesting that certain rootstocks may promote preemptive root colonizing symbionts that suppress root pathogens and provide indirect forms of ARD resistance.

The rootstocks 'M.7' and 'M.26' are standard commercial varieties grown in many regions, but there is little published information on their relative susceptibility to ARD.
In a comparison of rootstocks in replant and non-replant orchard sites, Robinson et al. (2002) found that 'M.7' trees grew equally well in both sites, while 'M.26' trees were $30 \%$ smaller in replant soil. In our study, tree growth on 'G.16', 'M.7', and 'M.26' improved when they were planted in the old grass lanes compared to old tree rows (Figs. 2A and C). Savory (1966) suggested planting new orchards perpendicular to previous tree rows in Britain, and Wilton (2002b) also encouraged avoiding the old tree rows in New Zealand. Taken collectively, these observations suggest that rotating newly planted trees out of previous orchard tree rows is a useful practice when feasible.

Yield trends. Rootstocks were the most important factor determining yields at our orchard, and there was a clear separation between 'CG.6210', 'G.30', and the other three rootstocks (Fig. 5A). Marini et al. (2002) described good tree survival, high annual yields, and adequate fruit size as attributes of the ideal rootstock; all of these traits were exemplified by 'CG.6210' in our study. Crop density on 'CG.6210' also exceeded that of other rootstocks, although this trait varied among PPSTs (Fig. 5B). Marini et al. (2002) noted that crop density and other measures of yield efficiency are more meaningful than total crop load for comparing tree performance on rootstocks of different vigor, as in our experiment. This distinction was evident in comparing tree performance on 'CG.6210' and 'G.30'. The former produced more total crop in 2004 and 2005 , but the two rootstocks were similar in terms of crop density (Fig. 5B). Trees on 'M.7' have been similar in scion vigor to 'CG.6210' and 'G.30' in other studies, and its poor performance in our study suggests that 'M.7' was relatively susceptible to the ARD complex. This observation has significant implications because 'M.7' is one of the most commonly planted rootstocks in North America.

\section{Conclusions}

Recent studies have shown that integrating various ARD control tactics such as rootstock selection, preplant soil treatments, and avoiding old tree rows could minimize orchard replant problems. Our research demonstrated that planting trees on new rootstocks such as 'CG.6210' and 'G.30' effectively controlled
ARD symptoms in a northeastern U.S. orchard. As chemical control options dwindle and concerns about the negative impacts of soil fumigation heighten, careful rootstock selection and replanting trees outside of old tree rows may provide more effective and economical control of ARD than preplant soil fumigation in some orchards.

\section{Literature Cited}

Agnello, A., A. Landers, W. Turechek, D. Rosenberger, T. Robinson, J. Schupp, J. Carroll, L. Cheng, P. Curtis, D. Breth, and S. Hoying. 2004. Pest management guidelines for commercial tree-fruit production 2004. Cornell Univ., Ithaca, N.Y.

Allen, W. and C. Marks. 1977. Chemical control and population studies of Pratylenchus penetrans on fruit free understocks. Plant Dis. Rptr. 61:84-87.

Benson, N., R. Covey, Jr., and W. Haglund. 1978. The apple replant problem in Washington state. J. Amer. Soc. Hort. Sci. 103:156-158.

Costante, J., W. Mai, J. Aleong, and R. Klein. 1987. Effects of apple rootstocks and nematicides on Pratylenchus penetrans populations and apple tree growth. J. Amer. Soc. Hort. Sci. 112:441-444.

Cummins, J. and H. Aldwinckle. 1983. Breeding apple rootstocks. Plant Breeding Rev. 1:294-394.

Forge, T., E. Hogue, D. Neilsen, and G. Neilsen. 2000. Organic soil amendments and mulches reduce population densities of the root-lesion nematode, Pratylenchus penetrans, in Okanagan orchards and vineyards. Can. J. Plant Pathol. 22:177 (abstr.).

Granatstein, D. and M. Mazzola. 2001. Alternatives to fumigation for control of apple replant disease in Washington state orchards. Nov. 2002. http://organic.tfrec.wsu.edu/OrganicIFP/AppleReplantDisease/IFPSpainProc.PDF.

Hoitink, H. and M. Grebus. 1994. Status of biological control of plant diseases with composts. Compost Sci. Utiliz. (Spring).

Hoitink, H. and P. Fahy. 1986. Basis for the control of soilborne plant pathogens with composts. Annu. Rev. Phytopathol. 24:93-114.

Isutsa, D. and I. Merwin. 2000. Malus germplasm varies in resistance or tolerance to apple replant disease in a mixture of New York orchard soils. HortScience 35:262-268.

Jaffee, B., G. Abawi, and W. Mai. 1982. Role of soil microflora and Pratylenchus penetrans in an apple replant disease. Phytopathology $72: 247-251$

Mai, W. and G. Abawi. 1981. Controlling replant diseases of pome and stone fruits in northeastern United States by preplant fumigation. Plant Dis. 65:859-864.

Mai, W., I. Merwin, and G. Abawi. 1994. Diagnosis, etiology and management of replant disorders in New York cherry and apple orchards. Acta Hort. 363:33-41.

Marini, R., J. Barden, J. Cline, R. Perry, and T. Robinson. 2002. Effect of apple rootstocks on average 'Gala' fruit weight at four locations after adjusting for crop load. J. Amer. Soc. Hort. Sci. 127:749-753.

Mazzola, M. 1998. Elucidation of the microbial complex having a causal role in the development of apple replant disease in Washington. Phytopathology 88:930-938.

McKenry, M. 1999. The replant problem and its management. Catalina Publ., Fresno, Calif.

Merwin, I. 1995. Managing orchard replant disease without toxic soil fumigants. N.Y. Fruit Qrtly. 


$$
3: 6-9 \text {. }
$$

Merwin, I., R. Byard, T. Robinson, S. Carpenter, S. Hoying, K. Iungerman, and M. Fargione. 2001. Developing an integrated program for diagnosis and control of replant problems in New York apple orchards. N.Y. Fruit Qrtly. 9:11-15.

Moran, R. and J. Schupp. 2001. The effect of preplant monoammonium phosphate and apple compost on the growth of newly planted apple trees. HortScience 36:451 (abstr.).

Niblack, T. and R. Hussey. 1985. Extracting nematodes from soil and plant tissue, p. 201-206. In: B. Zuckerman, W. Mai, and M. Harrison (eds.). Plant nematology: Laboratory manual. Univ. Mass. Agr. Expt. Sta., Amherst, Mass.

Parker, K. and W. Mai. 1974. Root diseases of fruit trees in New York state: Damage caused by Pratylenchus penetrans to apple trees in the orchard growing on different rootstocks. Plant Dis. Rptr. 58:1007-1011.

Robinson, T., S. Hoying, M. Fargione, K. Iungerman. 2002. On-farm trials of the Cornell-Geneva apple rootstocks in New York. N.Y. Fruit Qrtly. 10:22-26.

Rumberger, A., S. Yao, I. Merwin, E. Nelson, and J. Thies. 2004. Rootstock genotype and orchard replant position rather than soil fumigation or compost amendment determine tree growth and rhizosphere bacterial community composition in an apple replant soil. Plant Soil 264:247-260.

Savory, B. 1966. Specific replant diseases: Causing root necrosis and growth depression in perennial fruit and plantation crops. Cmwlth. Agr. Bur., England.

Smith, T. 1994. Successful management of orchard replant disease in Washington. Wash. State
Univ. Bul.

Stiles, W. and W. Reid. 1991. Orchard nutrition management. Cornell Coop. Ext. Bul. 219.

Utkhede, R., T. Vrain, and J. Yorston. 1992. Effects of nematodes, fungi, and bacteria on the growth of young apple trees grown in apple replant disease soil. Plant Soil 139:1-6.

Wilton, J.2002a. Orchard redevelopment in New Zealand (part I). Compact Fruit Tree. 35:122-123.

Wilton, J. 2002b. Orchard redevelopment in New Zealand (part II). Compact Fruit Tree. 35:124-125.

Yao, S. 2005. Soil microbial community analyses and root observations in apple replant and various groundcover management systems. PhD diss., Cornell Univ, Ithaca, N.Y. 